\title{
舌小帯短縮症の音声言語学的研究
}

九州䨑科大学第 2 口胺外科学教室 (指導 : 池尻 茂教授)

大学院生 堤 直 文

（昭和44年 9 月 9 日受理）

（本論文の要旨は，昭和44年 4 月26日第23回日本口腔科学会総会, 昭和44年 5 月24日第28回九州歯科学会総会, および昭和44年 9 月20日第15回日本口腔外科学会九州地方会に抢いて発表した）

\section{PHONETICAL AND PHILOLOGICAL STUDIES OF TONGUE-TIE}

\author{
By \\ Naofumi TSUTSUMI \\ Second Department of Oral Surgery (Director: Prof. Shigeru IKEJIRI) \\ Kyushu Dental College, Kitakyushu, Japan
}

In tongue-tie speech, speech disorders are classified as a functional disorder. The details of these disorders are not made clear yet.

Investigations were made on 8767 pupils by using the measuring apparatus for tongue extension degree, which was devised by myself. In these investigations, there were found 75 pupils of tongue-tie $2^{\circ}$ (mild group) and 8 pupils of tongue-tie $3^{\circ}$ (severe group) .

Out of these cases, lingual frenum plastic operations were performed on 8 pupils tonguetie $2^{\circ}$ and 5 pupils of tongue-tie $3^{\circ}$, who could cooperate with me. Before these operations and three months after the operations, the following tests and observations were made :

1) Speech intelligibility test, Speech articulation test

2) Observations of Palatogram

3) Observations of Sound Spectrogram

The results of the effect of tongue-tie on phonetic and philology are summerized as follows.

1. In a speech intelligibility test, pre-operative three-syllable intelligibility was more than $82 \%$. This means that tongue-tie speakers do not have so much trouble in every day conversation, but listeners notice a little peculiarity in their speech. After the operation, the intelligibility of both two-and three-syllable was improved.

2. In a speech articulation test, pre-operative articulation scores of monosyllable were more than $70.1 \%$. This corresponds to the slight speech disorder classified by Dr. Furuya. Post-operative articulation of both monosyllable and meaningless three-syllable was improved.

3. Observations of the palatogram, both before and after the operation, to compare the speech sounds of tongue-tie pupils with the speech sounds of normal speakers, showed no difference except in $\mathrm{R}$-sounds (enunciations of $\mathrm{R}$ followed by vowels). Pre-operative $\mathrm{R}$-sounds showed a difference from the normal. Post-operative $R$-sounds of tongue-tie $2^{\circ}$ showed close resemblance to the normal, but tongue-tie $3^{\circ}$ showed little improvement from the pre-operative $\mathrm{R}$-sounds. 
4. From the observations of the sound spectrogram, pre-operative consonants of R-sounds were obsucure, but after the operation, very clear. Variations of cycle elements were found in unvoiced sounds of $T$-sounds (enunciations of $T$ followed by vowels) compared with those of pre-operative consonants.

5. From the investigations by speech sounds, remarkable abnormalities were found only in R-sounds. But in R-sounds of tongue-tie, there was abnormality of speech articulation, palatogram and sound spectrogram. So it was comfirmed that tongue-tie had a great effect upon R-sounds. Post-operative R-sounds were improved.

As mentioned above, speech sounds of tongue-tie will cause speech disorders. The speech disorders of tongue-tie proved to be improved without speech clinic by lingual frenum plastic operation. From the phonetical and philological point of view, it seems best that lingual frenum plastic operation shoud be performed promptly in cases of tongue-tie.

目次

I. 緒 論

II. 舌小帯短縮症の語音発語了解度, 語音発語明瞭度に 関する研究

A. 研究目的拉よび方法

1. 目 的

2. 研究対象および装置

3. 研究方法

B. 語音発語了解度成績

1。3 音節語音発語了解度

2. 2 音節語音発語了解度

C. 語音発語明瞭度成績

1。単音節語音発語明瞭度

2 , 無意味 3 音節語音発語明瞭度

3. 語音別語音発語明瞭度

D. 小括

III. 舌小帯短縮症のパラトグラムによる調音研究

A. 研究目的拈よび方法

1. 目的

2. 研究対象扔よび装置

3. 研究方法

4. パラトグラム分類, 計測法

B．パラトグラム成績

1. 正常者群

2. 舌小帯短縮症 2 群

3. 舌小帯短縮症 3 群

C. 小括

IV. 舌小帯短縮症音声のサウンド・スペクトログラフに よる音声分析的研究

A. 研究目的および方法
1. 目的

2. 研究対象

3. 研究装置

4. 研究方法

B．サウンド・スペクトログラム成績

C. 小括

V. 総括ならびに考察

A. 研究方法について

B. 研究成績について

VI. 結 論

VII. 引用文献

\section{I 緒 論}

舌小帯短縮症は，歯科臨床において，しばしばみられ る口腔内の工奇形であり，種々な問題を提供するすので ある．本症に関する記載は，成書にも広くみられ，口腔 外科では，遠藤1), 佐藤2), 大井 ${ }^{3)}$, Thoma ${ }^{4)}$, Archer5) 等が，耳鼻咽喉科では，後藤6)，切替(7)，鳥居8)等により 記載され，また一般外科成書にもみられる。乙れらの成 書で, 本症の機能障害として, I，舌の運動障害， 2 。 言語障害, 3. 哺乳障害, 4 。霜科補 綴物 装着時の障 害，5．㐘列不正の原因等が記載されている99)。とのう ち，舌小帯短縮症の言語障害については，舌尖の運動 によって発音される音，特に滑音（ラ行音）が不明瞭 になるとされている，症例報告では，滑音に障害が みられた例 10 13) と，その他の音にも障害が認められた 例 14 19) がある。 また Mc Enery ${ }^{20)} は$ は，本症は必ずし あ調音障害をきたすとはいえないといい，田口21)は，本 症に上る言語障害に客観的証抛がみつからないといって いる. しかし，てれらの報告は，主として検者の主観的 な聴覚による観察だけで，本症の客観的な音声言語学的 
研究はなされていない。

音声言語学の研究にはいろいろな方法があり, 聴覚的 研究方法として, 語音発語了解度 (以下, 語了度と呼

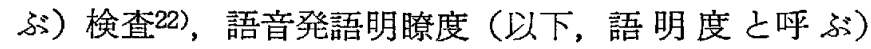
検查 23ー25)などがある．音声の調音運動を研究するため には X線映画 26,27) やリンゴグラム 28$)$ ， パラトグラム 28３1）による方法がある. 電気通信工学的な音声の分析 方法は，電磁オシロスコープ32)に始まり，現今は，サウ ンド・スペクトログラフ 33〜35) を利用する方法が用いら れている.

私は, 舌伸展度測定器によって, 舌小帯短縮症と診断 され36)，その程度別分類により，中等症，あるいは重症 の症例で，協力を得られたものに舌小带形成術を行なっ た。この本症術前, 術後に, 語了度, 語明度検查, パラ トグラムの観察，サウンド・スペクトログラフによる観 察を行ない，本症の音声言語に与える影響について研觉 を行なった。

\section{II 舌小帯短樎症の語音発語了解度, 語音発語明瞭度に 関する研究}

\section{A. 研究目的および研究方法}

工. 目 的

語了度検查 ${ }^{22)}$ は，社会的言語生活 の適 応をみる検查 で，換言すれば，「話しことば」の了解度を測るもので ある。語明度検査 ${ }^{37}$ は，言語障害の程度を聴覚的な結果 として，数量的に表現することで，被検者の言語能力を 推定する検査である．以上の語了度，語明 度 検查によ り，舌小帯短縮症の発音に及ぼす影響を聴覚的に明らか にするととを目的とする。

2. 研究対象および装置

対象：私が製作した舌伸展度測定器 ${ }^{36) （ F i g ~ l ） に 上 ~}$ り求めた自発的最大舌伸展值を, 同じ測定器から求めた 自発的最大開口值で除し，その值を舌小带短縮 度とし た. この值が，男子0.40以下，女子0.43以下を舌小帯短 縮症とした. さらにその軽重の程度を舌小帯短縮度によ って，3段階に分類した。 つまり， I 0.40 , 女子 $0.22 \sim 0.43,2^{\circ}$ は, 男子 $0.01 \sim 0.20$, 女子 $0.01 \sim 0.21,3^{\circ}$ は，男女とあ0である．乙の様にして 定めた舌小帯短縮症 $2^{\circ}$ は, 8767 名中 75 名, $3^{\circ}$ は, 8767名中, 8名であった。これらの症例者のうち，術前 之術後 3 ケ月目（以下，術後之呼㣻）に，語了度，語明 度検查が可能であった $2^{\circ} 8$ 名， $3^{\circ} 5$ 名，計13名を対象 とした。 なお全員とも中学生であり, 舌以外化調音器官 の異常はなく, 強いナマリや方言はなかった。

装置：本研究に使用した装置は，次のごとくである.
Fig 1. THE MEASURING APPARATUS
FOR TONGUE EXTENSION DEGREE

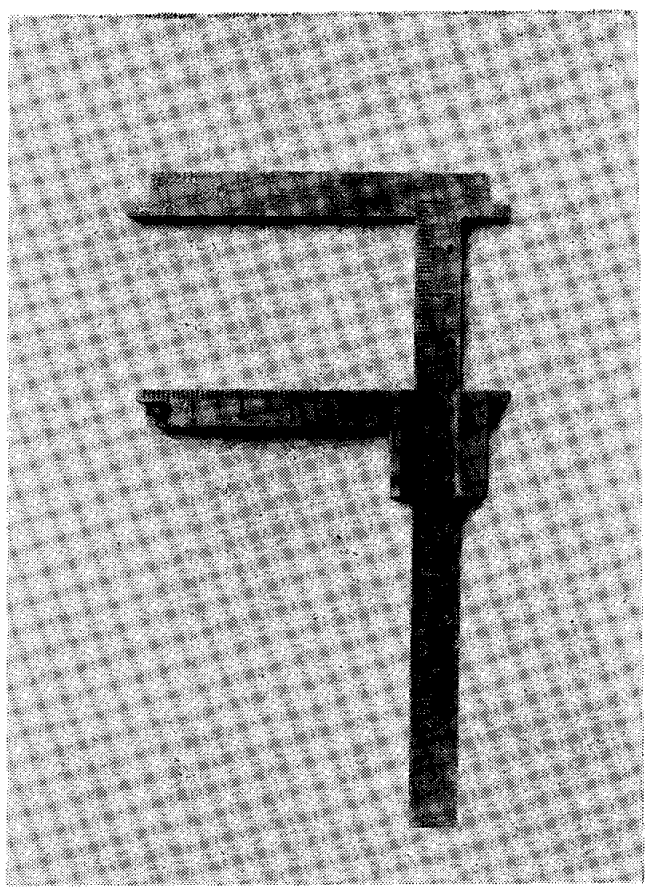

。 録音装置

Dynamic microphone F-96 (Sony 製)

Tape recorder

TC-350 (Sony 製)

\section{。再生装置}

Tape recorder TC-250A (Sony 製)

Stereo head phone SE-2D (pioneer 製)

増. 幅 器 $\quad$ L A -3115 (池上電信機製)

3. 研究方法

語了度検査語集 ${ }^{22}$ は，日本音響学会明瞭度委員会 ${ }^{37)}$ に 扔いて選定された，有意味 3 音節㧍よび 2 音節の1400単 語中より作成したもので, at randomにならべかえた50 单語を1組の検査語集としたものである．有意味 3 音節 扔よび 2 音節語了度検查語集は，各々25組作製した。語 明度検查語集22)は，拗音，促音を除く日本語67音による 単音節および無意味 3 音節で, 両検查語集とも各々 40 組 作製した．単音節は，工組の検查語集に，日本語67音 が, at random に必ず】回でてくる，無意味 3 音節は， 日本語67音を用いて全く意味を有しない組合せにしたも ので，1組の検查語集中，67音が各音節ごとに必ず】回 均等に出てくるようにしてある，乙の語了度検查語集か ら有意味 3 音節， 2 音節とす 1 組づつ選定し，語明度検 查語集から単音節, 無意味 3 音節とも 2 組づつ選定して 検查を行なった。

語了度, 語明度の検查は, 被検者に防音室内で検査語 集を読ませて，乙れを前記した録音装置を用いて録音し 
た. 録音場所は，熊本大学医学部耳鼻咽喉科聴力検查室 である．聴取方法は，高寄25)の方法に準じ，言語治療に 3 年以上の経験のある私が，前記した再生装置を用いて 聴取し，聴えたようにそのまま書取り記録し，後に検查 語集と比較対照した，語了度検查では，正しく発音され た百分率を被検者の語了度とし，語明度検査では，検査 語集 2 組の正しく発音された百分率の平均值を被検者の 語明度とした。 以上の検查を術前と術後に行なった。

\section{B．語音発語了解度成續}

3 音節および 2 音節語了度の分布は，Table 1 亿示す ごとくとなり，症例ごとの術前と術後の差の分布は， Table 2 に示すごとくであった。

Table 1 Speech Intelligibility Scores

\begin{tabular}{|c|c|c|c|c|}
\hline \multirow{2}{*}{$\begin{array}{c}\text { Speech } \\
\text { Intelligibility } \\
(\%)\end{array}$} & \multicolumn{2}{|c|}{ 3-Syllable } & \multicolumn{2}{|c|}{ 2-Syllable } \\
\hline & Pre. & Post. & Pre. & Post. \\
\hline $0 \sim 1.0$ & & & & \\
\hline $10.1 \sim 20$ & & & & \\
\hline $20.1 \sim 30$ & & & & \\
\hline $30^{\circ} I \sim 40$ & & & & \\
\hline $40.1 \sim 50$ & & & & \\
\hline $50.1 \sim 60$ & & & & \\
\hline $60.1 \sim 70$ & & & 1 & 1 \\
\hline $70.1 \sim 80$ & & & 1 & 0 \\
\hline $80.1 \sim 90$ & 6 & 1 & 7 & 1 \\
\hline $90.1 \sim 100$ & 7 & 12 & 4 & 1.1. \\
\hline Total & 13 & 13 & 13 & 13 \\
\hline
\end{tabular}

Pre. ….... Pre-Operation

Post. ….....Post-Operation

The numbers in these tables are the ones of patie$n$ ts with tongue-tie in each case.

Table 2

Distribution of the Difference between Post-and Pre-Operative Speech Intelligibility Scores.

\begin{tabular}{c||c|c|c||c|c|c}
\hline $\begin{array}{c}\text { Post. -Pre. } \\
\text { Speech } \\
\text { Intelligibility } \\
\text { (\%) }\end{array}$ & $2^{\circ}$ & $3^{\circ}$ & Total & $2^{\circ}$ & $3^{\circ}$ & Total \\
\hline 20.1 & & & & & & \\
$15.1 \sim 20$ & & & & 2 & 1 & 3 \\
$10.1 \sim 15$ & 1 & 1 & 2 & 0 & 0 & 0 \\
$5.1 \sim 10$ & 2 & 3 & 5 & 3 & 1 & 4 \\
$0 \sim 5$ & 4 & 1 & 5 & 3 & 1 & 4 \\
\hline$-0.1 \sim-5$ & & & 1 & & 1 & 1 \\
$-5.1 \sim-10$ & 1 & & & & 1 & 1 \\
\hline
\end{tabular}

1。 3 音節語音発語了解度

3 音節語了度の術前の結果注，最高 $100 \%$ ，最低 $82 \%$ で，術後は，最高100\%，最低 $90 \%$ であった，語了度 80.1.\%以上の症例は, 術前, 術後とも13例中13例であっ た。各症例ごとに術前と術後の語了度の変化を観察し， 術後の語了度が増したものを十，減じたものを一とする と, Table 2 のごとくであった。 +の症例数，つまり術 後に術前上り高い語了度を示した症例数は，本症 $2^{\circ}$ が 8 例中 7 例, $3^{\circ}$ か 5 例中 5 例，計13 例中 12 例化認め られた。

\section{2 音笝語音発語了解度}

2 音節語了度の術前は，最高 $96 \%$ ，最低 $68 \%$ で，術後 は，最高 100\%，最低70\%であった，術前語了度が80.1 $\%$ 以上の症例は，四例であったが，術後は工2例上工例の 增加がみられた．各症例ごとに術前と術後の語了度の変 化をみると，術後に術前より高い語了度が得られた症例 は，本症 $2^{\circ}$ が 8 例中 8 例， $3^{\circ}$ が 5 例中 3 例で，計13 例中工工例に認められた。

\section{C. 語音発語明瞭度成續}

単音節扮よび無意味 3 音節語明度の分布は，Table 3 に示すごとくとなり，症例ごとの術前之術後の差の分布 は，Table 4 亿示すごとくであり．語音別語明度の分布 は, Table 5 のごとくであった。

1. 単音節語音発語明瞭度

本症術前の単音節語明度は，最高94.0\%，最低70.1\% で，術後の語明度は，最高 $97.8 \%$, 最低 $82.1 \%$ であっ た。 また $80.1 \%$ 以上の症例は，術前の]1例から術後の13 例へと 2 例の増加がみられた，次に各症例どとに術前と 術後の語明度の変化をみると, 術後に術前上り高い語明 度が得られた症例は，本症 $2^{\circ}$ が 8 例中 7 例， $3^{\circ}$ が 5 例 中 4 例で，計13例中几例に認められた。

\section{2. 無意味 3 音節語音発語明瞭度}

無意味 3 音節語明度は，術前，最高86.6\%，最低29.1 \%で，術後は，最高 $94.0 \%$ ，最低 $45.5 \%$ だった。 また $60.1 \%$ 以上の語明度を示した症例は，術前13例中 8 例だ ったのに，術後は13例中12例之4例の増加がみられた。 次に，各症例ごとに術前 と術 後の語明度の変 化をみる 上，術後に術前上り高い語明度か得られた症例は，本症 $2^{\circ}$ が 8 例中 6 例， $3^{\circ}$ が 5 例中 4 例で，計13例中10例に 認められた。

\section{3. 語音別語音発語明瞭度}

単音節語明度検查の結果を語音別に分析したのが, 語 音別語明度である。

母音，半母音：2 者とも80.1\%以上の語明度を示す症 
Table 3 Speech Articulation Scores

\begin{tabular}{|c|c|c|c|c|}
\hline \multirow{2}{*}{$\begin{array}{c}\text { Speech } \\
\text { Articulation } \\
(\%)\end{array}$} & \multicolumn{2}{|c|}{ Monosyllable } & \multicolumn{2}{|c|}{$\begin{array}{l}\text { Meaningless } \\
3 \text {-Syllable }\end{array}$} \\
\hline & Pre. & Post. & Pre. & Post. \\
\hline $0 \sim 10$ & & & & \\
\hline $10.1 \sim 20$ & & & & \\
\hline $20.1 \sim 30$ & & & 1 & \\
\hline $30.1 \sim 40$ & & & 0 & \\
\hline $40.1 \sim 50$ & & & 1 & I \\
\hline $50.1 \sim 60$ & & & 3 & 0 \\
\hline $60.1 \sim 70$ & & & 3 & 5 \\
\hline $70.1 \sim 80$ & 2 & & 2 & 4 \\
\hline $80.1 \sim 90$ & 6 & 4 & 3 & 2 \\
\hline $90.1 \sim 100$ & 5 & 9 & 0 & 1 \\
\hline Total & 13 & 13 & 13 & 13 \\
\hline
\end{tabular}

The numbers in these tables are the ones of patients with tongue-tie in each case.
Table 4

Distribution of the Difference between Post-and Pre-Operative Speech Articulation Scores.

\begin{tabular}{|c|c|c|c|c|c|c|}
\hline \multirow{2}{*}{$\begin{array}{c}\text { Post. -Pre. } \\
\text { Speech } \\
\text { Articulation } \\
(\%)\end{array}$} & \multicolumn{3}{|c|}{ Monosyllable } & \multicolumn{3}{|c|}{$\begin{array}{l}\text { Meaningless } \\
3 \text {-Syllable }\end{array}$} \\
\hline & $2^{\circ}$ & $3^{\circ}$ & Total & $2^{\circ}$ & $3^{\circ}$ & Total \\
\hline $20.1 \sim$ & & & & 2 & & 2 \\
\hline $15.1 \sim 20$ & 1 & & 1 & 0 & 3 & 3 \\
\hline $10.1 \sim 15$ & 1 & 1 & 2 & 1 & 0 & 1 \\
\hline $5.1 \sim 10$ & 2 & 1 & 3 & 3 & 1 & 4 \\
\hline $0 \sim 5$ & 3 & 2 & 5 & 0 & 0 & 0 \\
\hline $\begin{array}{l}-0.1 \sim-5 \\
-5.1 \sim-10\end{array}$ & 1 & 1. & 2 & 2 & $\begin{array}{l}0 \\
1\end{array}$ & $\begin{array}{l}2 \\
1\end{array}$ \\
\hline
\end{tabular}

Table 5

Speech Articulation Scores by Each Sound

\begin{tabular}{|c|c|c|c|c|c|c|c|c|c|c|c|c|c|c|}
\hline \multirow{2}{*}{$\begin{array}{c}\text { Speech } \\
\text { Articulation } \\
(\%)\end{array}$} & \multicolumn{2}{|c|}{ Vowel } & \multicolumn{2}{|c|}{ Semi-vowel } & \multicolumn{2}{|c|}{ Nasal } & \multicolumn{2}{|c|}{$\mathrm{H}$-sounds } & \multicolumn{2}{|c|}{$\begin{array}{l}\text { Voiced } \\
\text { - sounds }\end{array}$} & \multicolumn{2}{|c|}{$\begin{array}{l}\text { Unvoiced } \\
\text {-sounds }\end{array}$} & \multicolumn{2}{|c|}{$\mathrm{R}$-sounds } \\
\hline & Pre. & Post. & Pre. & Post. & Pre. & Post. & Pre. & Post. & Pre. & Post. & Pre. & Post. & Pre. & Post. \\
\hline $0 \sim 10$ & & & & & & & & & & & & & & \\
\hline $10.1 \sim 20$ & & & & & & & & & & & & & & \\
\hline $20.1 \sim 30$ & & & & & & & 1 & & & & & & & \\
\hline $30.1 \sim 40$ & & & & & & & 0 & & & & & & & \\
\hline 40.I 50 & & & & & & & 0 & & & & & & 2 & \\
\hline $50.1 \sim 60$ & 1 & & & & & 1 & 0 & & & & & & 0 & \\
\hline $60.1 \sim 70$ & 0 & & & & 5 & 0 & 3 & 1 & 1 & & & & 4 & 1. \\
\hline $70.1 \sim 80$ & 2 & 1. & & 1 & 2 & 3 & 2 & 1 & 2 & 1 & 2 & & 2 & 1 \\
\hline $80.1 \sim 90$ & 0 & 2 & 2 & 3 & 3 & 7 & 3 & 3 & 7 & 5 & 6 & 4 & 2 & 3 \\
\hline $90.1 \sim 100$ & 1.0 & 10 & 11 & 9 & 3 & 2 & 4 & 8 & 3 & 7 & 5 & 9 & 3 & 8 \\
\hline Total & 13 & 13 & 13 & 13 & 13 & 13 & 13 & 13 & 13 & 13 & 13 & 13 & 13 & 13 \\
\hline
\end{tabular}

$\mathrm{H}$-sounds ......... Enunciations of $\mathrm{H}$ followed by vowels

$\mathrm{R}$-sounds........Enunciations of $\mathrm{R}$ followed by vowels

例が大多数で, 術前, 術後に差異はみられなかった。

鼻音: 術前の語明度が80.1\%以上は，6例だったの に, 術後は 9 例之増加していた。

八行音：術前の語明度が80.1\%以上は，7例であった が，術後は1工例之増加していた。

有声子音 : 術前に80.1\%以上の語明度を示す症例は10 例だったが，術後は12例と増加がみられた。

無声子音：術前の語明度が80.1\%以上は，11例だった のに，術後は13例と増加していた。

滑音 : 術前の語明度が, $80.1 \%$ 以上の症例は 5 例だっ
たが，術後は工例となり，6例の著明な増加がみられ た.

D. 小 括

舌小帯短縮症の術前と術後に観察出来た舌小帯短縮症 $2^{\circ} 8$ 名, $3^{\circ} 5$ 名, 計13名について語了度, 語明度検 査を行なった。

語了度検査の結果，3 音節語了度は，術前，最高 100 $\%$ ，最低82\%で，術後は，最高100\%“最低 90 多であっ た２ 音節語了度は，術前，最高96\%，最低68\%で，術 後は，最高100\%，最低 $70 \%$ たった。よ゙ちらの音節 
も, 最高, 最低の語了度は, 術前に較へ, 術後上昇して いた．各症例ごとに術前之術後の変化をみると，3音 䬣，2 音節とも大多数の症例が，術後に術前より高い語 了度を示した。

語明度検査の結果，単音節語明度は，術前，最高94.0 $\%$ ，最低70.1\%で，術後は最高97.8\%，最低82.1\%であ った。 無意味 3 音節は，術前，最高86.6\%，最低 $29.1 \%$ で, 術後は, 最高 $94.0 \%$, 最低 $45.5 \%$ であった。乙のよ うにどちらの音節と屯, 最高, 最低の語明度は, 術前に 較べ術後上昇していた，各症例ごとに術前之術後の変化 をみると，3音節， 2 音節とあ大多数の症例が，術後に 術前より高い語明度を示した。

語了度, 語明度検查では, 本症 $2^{\circ}$ と $3^{\circ}$ の間には, 著 明な差異は認められなかった。

語音別語明度検查の結果, 語明度80.1\%以上の症例数 が, 術前と比較して, 術後に最む増加したのは滑音であ り，次に八行音，鼻音の順であった，その他の語音も， わずかではあるが，術後沭前より高い語明度を示す傾 向が認められた。

\section{III 舌小帯短縮症のパラトグラムによる調音研究 A. 研究目的および研究方法}

1. 目 的

音声言語学の重要な研究に，調音体としての舌の運動 がある 38 40). この調音運動の際の舌運動を描記する方 法としてパラトグラフィがあり，この舌運動を口蓋板 に描記して得た記録がパラトグラムである 28 31). 舌 は，パラトグラムにおいて，最む重要な要素の一つであ るが, 舌の形態、機能とパラトグラムとの関係について は，今まで述べられていない，一方，舌小帯短縮症は， 成書1 8) で舌の運動障害を指摘され，そのために帚語障 害をきたすと記載されている。しかし，舌小帯短縮症に おける舌の調音運動を観察した報告は。いまだみられな い. 私は, 舌の形態異常の一つである舌小帯短縮症の調 音運動をパラトグラムにより観察し，その調音状態を明 らかにすることを目的として研究を行なった。

2 . 研究対象および装置

対象 : 対照群として, 柬列, 咬合状態に異常なく, 舌 およびその他の調音器官が形態的, 機能的に正常で, 強 い方言や，ナマリのない16名を，正常者群とした．舌小 帯短縮症 $2^{\circ}$ の術前 9 名, 術後 8 名を舌小帯短縮症 $2^{\circ}$ 群 とした. また, 舌小帯短縮症 $3^{\circ}$ の術前, 術後の5名 を, 舌小帯短縮症 $3^{\circ}$ 群とした. 以上の延 43 名を対象と した.

装置 : 被検者の上頼模型を 2 個製作し，工個は，口蓋
板の製作に使用し，他の工個は，その模型基底面を眼耳 平面に平行な颏態模型とし，パラトグラムの計測に使用 した。 パラトグラム採取に用いる口蓋板は，口腔外科に おける口蓋保護床の製作法に準じて，森田31)の記载した 方法と同じく，厚さ0.15mm の合成樹脂板を用いて製作 した.

\section{3 , 研究方法}

被検者：検查時の語音として，日本語67語音中より， 母音と，パラトグラムで接触像の著明にみられるサ行 音, 夕行音, 力, ナ，ヤ，そ机に舌小帯短縮症で言語障 害のあらわれるといわれる滑音の計23音を用いた。

パラトグラム採取方法：被検者の口蓋板を口腔内に装 着し、被検者に口蓋板をできるだけなれさせる，なれる まで場合によっては，2〜3日装着しておく， 口蓋板の 異和感を感じなくなった後に，被検者の眼平平面がおお よそ水平になるように椅子に坐らせる，次に口蓋板表面

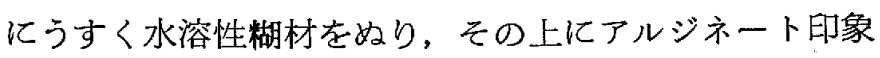
材の粉末を均一に塗布して口蓋流着し，通常の会話時 の大きさの声で，被検音を発音させる．ただちに口蓋板 を取り出し，眼耳平面を基準とした顎態模型にもどす。 こののちスクウェアを用いて，眼耳平面上の紙面に投影 して，各人各音のパラトグラムを採取記録した。

4. パラトグラム分類，計測法

パラトグラム分類型による研究：パラトグラムを荒井 30) の分類型に従って，Fig 2 のように, V 型, C型, N 型，H型，U型の 5 型に分類し観察した. これにより舌 の口蓋への接触形態がわかる.

パラトグラム示数計測による研究：模型上の眼耳平面 の紙面に投影されたパラトグラムの計測による研究を行 なった，計測は，まず上顎犬歯から第 2 大臼菌までの各 歯牙の近遠心最大幅径の中心を求め, この左右同名蒾牙 の中心を結び，同名歯牙の歯頸部との交点間を，同名歯 牙の口蓋幅径とした，パラトグラムにおいて，各䨑牙の 口蓋幅径楾上の接触部分を，口蓋幅径が 100 となる示数 に換算し，これをパラトグラム示数とした。（Fig 3) この方法をパラトグラム示数計測法とした. 各人各音の 部位別パラトグラム示数を求め, 対象各群ごとに各音

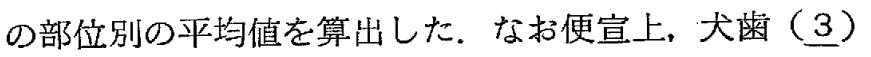
相当部より前方部を前方口蓋部，小臼歯 ( 4 드) 相当部

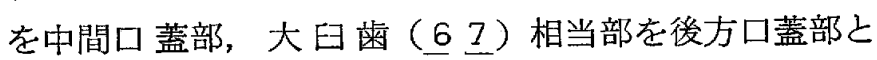
呼ぶことにする．このようにして，各部位のパラトグラ ム示数を算出することにより，口蓋の部位ごとの接触度 合を知ることができる. 
Fig 2 PALATOGRAM TYPE
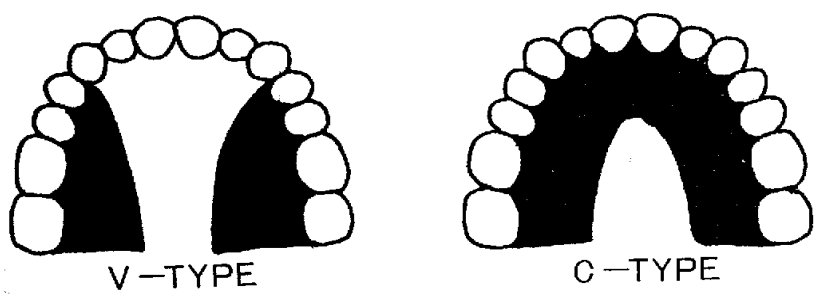

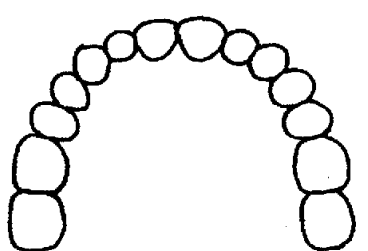

N-TYPE

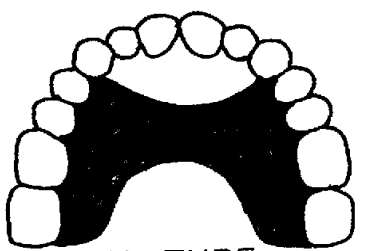

$\mathrm{H}-\mathrm{TYPE}$

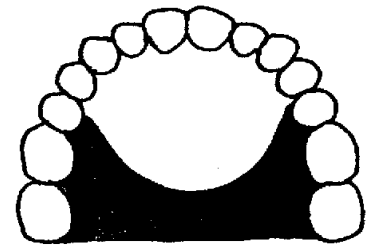

$U-T Y P E$
Fig 3 PALATOGRAM INDEX (Example)

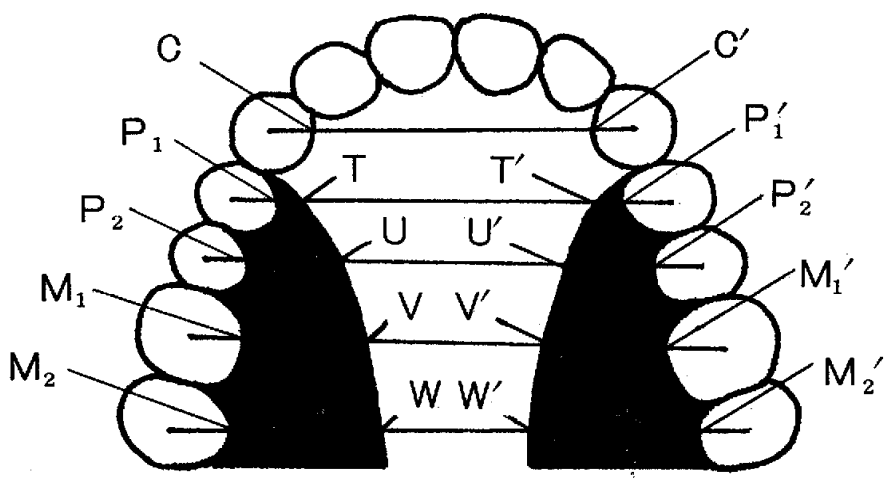

[sa]

Palatogram Index of $\underline{6}$ in sa-Sound

$$
=\frac{\mathrm{M}_{1} \cdot \mathrm{V}+\mathrm{M}_{1}^{\prime} \cdot \mathrm{V}^{\prime}}{\mathrm{M}_{1} \cdot \mathrm{M}_{1}^{\prime}} \times 1.00
$$

\section{B．パラトグラム成紸}

パラトグラム分類型の成績 : 荒井30)によるパラトグラ ムの分類型に従がった各群の分類型別の症例数を各音で とに記すと，Table 6，7，8，9，10k示すでとくで ある。

パラトグラム示数計測法の成績 : パラトグラム示数計 測法で求めた各群ごとの各音の部位別示数平均値を算出 し、各音ごとに別々に，各群の各部位のパラトグラム示 数平均值を結ぶと Fig 4 のでとくである.

以下各群ごとに,パラトグラムの特性について述へる.

\section{1. 正常者群}

母音：「ア」「オ」は，すべてN型であった。「イ」 「エ」は，すべてV型であり，「ウ」あ大多数がV型で あった. パラトグラム示数計測法による成績をみると，

「イ」は，後方口蓋部での示数が高く，前方口蓋部で低
かった.「ウ」「エ」は，後方口蓋部での示数が高かった。 サ行音：「サ」「ス」「セ」「ソ」は，大多数がV型 で，一部C型だった。「シ」は，ほとんどがV型であっ た。 パラトグラム示数計測法による成績をみると，「サ 」「ス」「セ」「ソ」は, 前方口蓋部の示数が高く, 中 間, 後方口蓋部の示数が低かった。「シ」は，中間，後 方口蓋部の示数が高かった。

夕行音：「夕」「ツ」「テ」「ト」は，ほとんどC型 であった，「チ」は，大多数が C型で，一部型であっ た。 パラトグラム示数計測法による成績をみると，タ行 音の各音とも, 前方口盖部の示数が高く, 中間, 後方口 蓋部では低汃った。

カ・ナ・ヤ音：「力」は，U型が多く，つぎにN型， V 型の順にみられた.「ナ」は、ほとんどがC型であった。

「ヤ」は，すべてV型だった，パラトグラム示数計測法 による成績でみると，「力」は，後方口蓋部で示数が高 かった。「ナ」は，前方口蓋部で示数が高く，後方口蓋 部は低かった。「ヤ」は，中間，後方口蓋部で示数が高 く, 前方口蓋部の示数は低かった。

滑音：滑音は，各音ともすべてH型であった，パラト グラム示数計測法による成蹟でみると，各音とも，中間 口蓋部の示数が高く，前方口蓋部の示数は低かった。

2 ，舌小帯短縮症 $2^{\circ}$ 群

術前：母音, 少行音, 夕行音, カ・ナ・ヤ音の各音 は，正常者群のそれと同じ接触形態を示し，また口蓋の 各部位でほぼ同じ接能度合を示した。しかし，滑音は， ほとんどC 型で，一部 H型をなし，パラトグラム示数計 測法では，各音とす前方口蓋部の示数が高く，後方口莣 になるに従がって低くなっていた。 
Table 6

Palatogram Types of The Normal

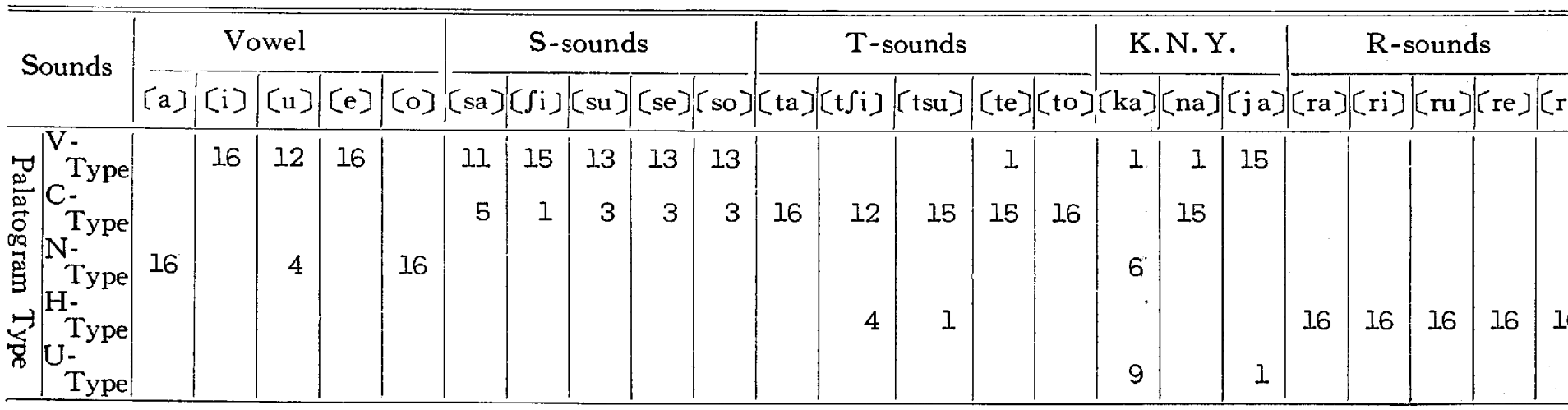

These Phonetic Symbols above are based on the International Phonetic Association. These characte $\mathbf{s i s t i c}$ speech sounds are found only in Japanese Language.

$\mathrm{S}$-sounds .........Enunciations of $\mathrm{S}$ followed by vowels

$T$-sounds …......Enunciations of $T$ followed by vowels

$\mathrm{R}$-sounds.........Enunciations of $\mathrm{R}$ followed by vowels

The numbers in these tables are the ones of patients with tongue-tie in each case.

Table 7

Palatogram Types of Pre-Operative Tongue-Tie $2^{\circ}$

\begin{tabular}{|c|c|c|c|c|c|c|c|c|c|c|c|c|c|c|c|c|c|c|c|c|c|c|c|}
\hline \multirow{2}{*}{ Sounds } & \multicolumn{5}{|c|}{ Vowel } & \multicolumn{5}{|c|}{ S-sounds } & \multicolumn{5}{|c|}{$\mathrm{T}$-sounds } & \multicolumn{3}{|c|}{ K.N.Y. } & \multicolumn{5}{|c|}{$\mathrm{R}$-sounds } \\
\hline & {$[a]$} & [i] & {$[u]$} & {$[\mathrm{e}]$} & {$[0]$} & {$[\mathrm{sa}]$} & {$[\mathrm{Si}]$} & {$[\mathrm{su}]$} & {$[\mathrm{se}]$} & [so] & {$[\mathrm{ta}]$} & ]$[(\mathrm{t} S \mathrm{i}]$ & {$[\mathrm{tsu}]$} & {$[\mathrm{te}]$} & [to] & {$[\mathrm{ka}]$} & {$[\mathrm{na}]$} & {$[\mathrm{ja}]$} & {$[\mathrm{ra}]$} & [ri] & {$[\mathrm{ru}]$} & {$[\mathrm{re}]$} & Cr \\
\hline
\end{tabular}

Table 8

Palatogram Types of Post-Operative Tongue-Tie $2^{\circ}$

\begin{tabular}{|c|c|c|c|c|c|c|c|c|c|c|c|c|c|c|c|c|c|c|c|c|c|c|c|}
\hline \multirow{2}{*}{ Sounds } & \multicolumn{5}{|c|}{ Vowel } & \multicolumn{5}{|c|}{ S-sounds } & \multicolumn{5}{|c|}{$\mathrm{T}$-sounds } & \multicolumn{3}{|c|}{ K.N.Y. } & \multicolumn{5}{|c|}{$\mathrm{R}$-sounds } \\
\hline & [a] & [i] & {$[\mathrm{u}]$} & [e] & [o] & {$[\mathrm{sa}]$} & {$[(\mathrm{i})$} & {$[\mathrm{su}]$} & [se] & [so] & [ta] & {$\left[\mathrm{t} \int \mathrm{i}\right]$} & {$[\mathrm{tsu}]$} & [te] & [to] & [ka] & [na] & {$[\mathrm{ja}]$} & Cra & {$[\mathrm{ri}$} & ru & & \\
\hline
\end{tabular}


Table 9

Palatogram Types of Pre-Operative Tongue-Tie $3^{\circ}$

\begin{tabular}{|c|c|c|c|c|c|c|c|c|c|c|c|c|c|c|c|c|c|c|c|c|c|c|c|}
\hline \multirow{2}{*}{ Sounds } & \multicolumn{5}{|c|}{ Vowel } & \multicolumn{5}{|c|}{ S-sounds } & \multicolumn{5}{|c|}{$\mathrm{T}$-sounds } & \multicolumn{3}{|c|}{ K.N.Y. } & \multicolumn{5}{|c|}{$\mathrm{R}$-sounds } \\
\hline & [a] & [i] & {$[\mathbf{u}]$} & {$[\mathrm{e}]$} & [0] & {$[\mathrm{sa}]$} & {$[\mathrm{Si}]$} & [su] & {$[\mathrm{se}]$} & [so] & {$[\mathrm{ta}]$} & {$\left[t \int i\right]$} & {$[\mathrm{tsu}]$} & {$[\mathrm{te}]$} & {$[$ to $]$} & {$[\mathrm{ka}]$} & {$[\text { na }]^{\prime}$} & {$[\mathrm{ja}]$} & [ra] & ]$[\mathrm{ri}]$ & {$[\mathrm{ru}]$} & {$[\mathrm{re}]$} & [ro] \\
\hline 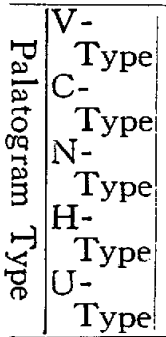 & 5 & 5 & 5 & 5 & 5 & $\begin{array}{l}3 \\
2\end{array}$ & 5 & 5 & 5 & $\begin{array}{l}4 \\
1\end{array}$ & $\begin{array}{l}4 \\
1\end{array}$ & $\begin{array}{l}3 \\
2\end{array}$ & 5 & 5 & 5 & $\begin{array}{l}1 \\
4\end{array}$ & $\begin{array}{l}4 \\
1\end{array}$ & $\begin{array}{l}4 \\
1\end{array}$ & 5 & 5 & 5 & 5 & 5 \\
\hline
\end{tabular}

Table 10

Palatogram Types of Post-Operative Tongue-Tie $3^{\circ}$

\begin{tabular}{|c|c|c|c|c|c|c|c|c|c|c|c|c|c|c|c|c|c|c|c|c|c|c|c|}
\hline \multirow{2}{*}{ Sounds } & \multicolumn{5}{|c|}{ Vowel } & \multicolumn{5}{|c|}{ S-sounds } & \multicolumn{5}{|c|}{$T$-sounds } & \multicolumn{3}{|c|}{ K. N.Y. } & \multicolumn{5}{|c|}{$\mathrm{R}$-sounds } \\
\hline & [a] & {$[i]$} & {$[u]$} & {$[e]$} & {$[0]$} & {$[\mathrm{sa}]$} & {$\left[\int i\right]$} & {$[\mathrm{su}]$} & $(\mathrm{se})$ & {$[\mathrm{so}]$} & {$[\mathrm{ta}]$} & {$[t / i]$} & {$[\mathrm{tsu}]$} & {$[\mathrm{te}]$} & {$[$ to $]$} & {$[\mathrm{ka}]$} & {$[n a]$} & {$[\mathrm{ja}]$} & {$[\mathrm{ra}]$} & {$[\mathrm{ri}]$} & {$[\mathrm{ru}]$} & {$[$ re $]$} & [ro] \\
\hline 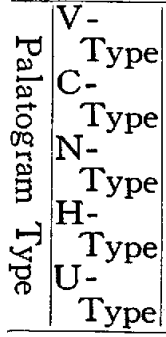 & 5 & 5 & 5 & $\begin{array}{l}4 \\
I\end{array}$ & 5 & $\begin{array}{l}3 \\
2\end{array}$ & 5 & 5 & 5 & 5 & 5 & $\begin{array}{l}4 \\
1 \\
1\end{array}$ & 1 & 5 & 5 & 5 & 5 & 5 & 4 & 4 & $\begin{array}{l}4 \\
1\end{array}$ & $\begin{array}{l}4 \\
1\end{array}$ & $\begin{array}{l}4 \\
1\end{array}$ \\
\hline
\end{tabular}

術後 : 滑音以外の各音は, 術前之変りなく, 正常者群 と同じ様相を示した，滑音は， $\mathrm{H}$ 型と C 型が ほ ぼ半々 で, パラトグラム示数計測法によると, 中問口蓋部の示 数が高く, 次に前方口蓋部が高かった，てのように滑音 のパラトグラムは, 術前より変化していた。

\section{3. 舌小帯短縮症 3 群}

術前：母音, サ行音, 夕行音, 力・ナ・中音の各音 は，正常者群のそれと同じ接触形態を示し，また口蓋の 各部位でほぼ同じ接触度合を示した。しかし，滑音は， 正常者群, 舌小帯短縮症 2 ○群術前とも異なり,すべて C 型であった. パラトグラム示数計測法による之, 各音 とも前方口蓋部の示数は 100 で, 中間, 後方口蓋部での 示数は低かった。

術後: 滑音以外の各音は, 術前之変りなく, 正常者群 と同じ様相を示した．滑音は，C型がほとんどであり， パラトグラム示数計測法によってあ，術前とあまり変り なく，前方口蓋部の示数が一番高かった，てのように，
滑音は, 術前とほぼ同じ様相を示し, 術後にあまり変化 は認められなかった。

\section{C. 小括}

3群よりなる対象, 延数43名について，日本語67音中 23音のパラトグラムを採取し，記録した。 パラトグラム は，分類型による方法と，私が考案したパラトグラム示 数計測法によって, 調音時の舌之口蓋の接触形態, 接触 度合を観察した。

\section{○正常者群}

母音の「ア」「オ」は，N型であった。「イ」「ウ」 「エ」の各音は，V型で後方口蓋部での接触度合が高く 認められた。

サ行音は，ほとんどがV型で，前方口蓋部の接触度合 が高かった，ただし，「シ」は，中間，後方口蓋部の接 触度合が高かった。

タ行音は，ほさんどC 型で，前方口蓋部での接触度合 が高かった。 


\section{Fig 4 PALATOGRAM INDEX GRAPH}

Each line in these figures connects the average of the palatogram index of each group of speech sounds.
p.i. palatogram index

p.p. .palatal part
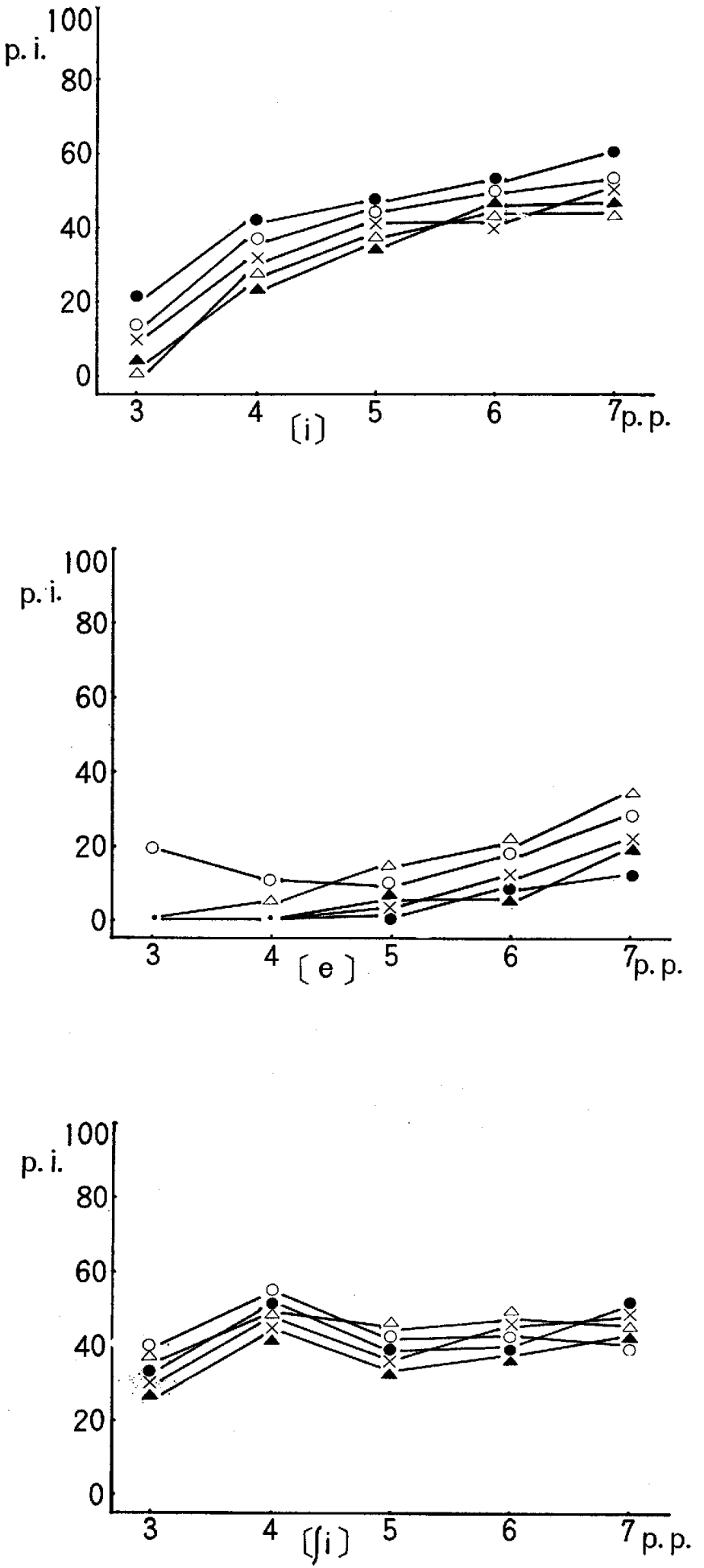
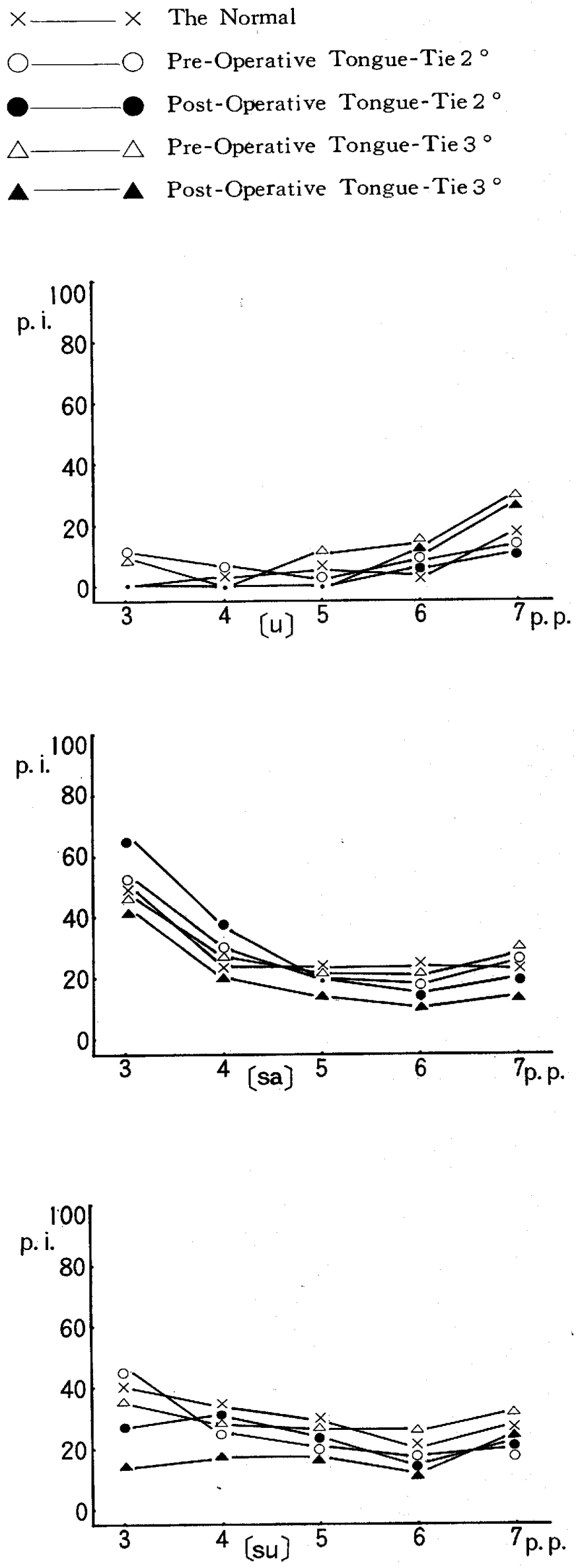

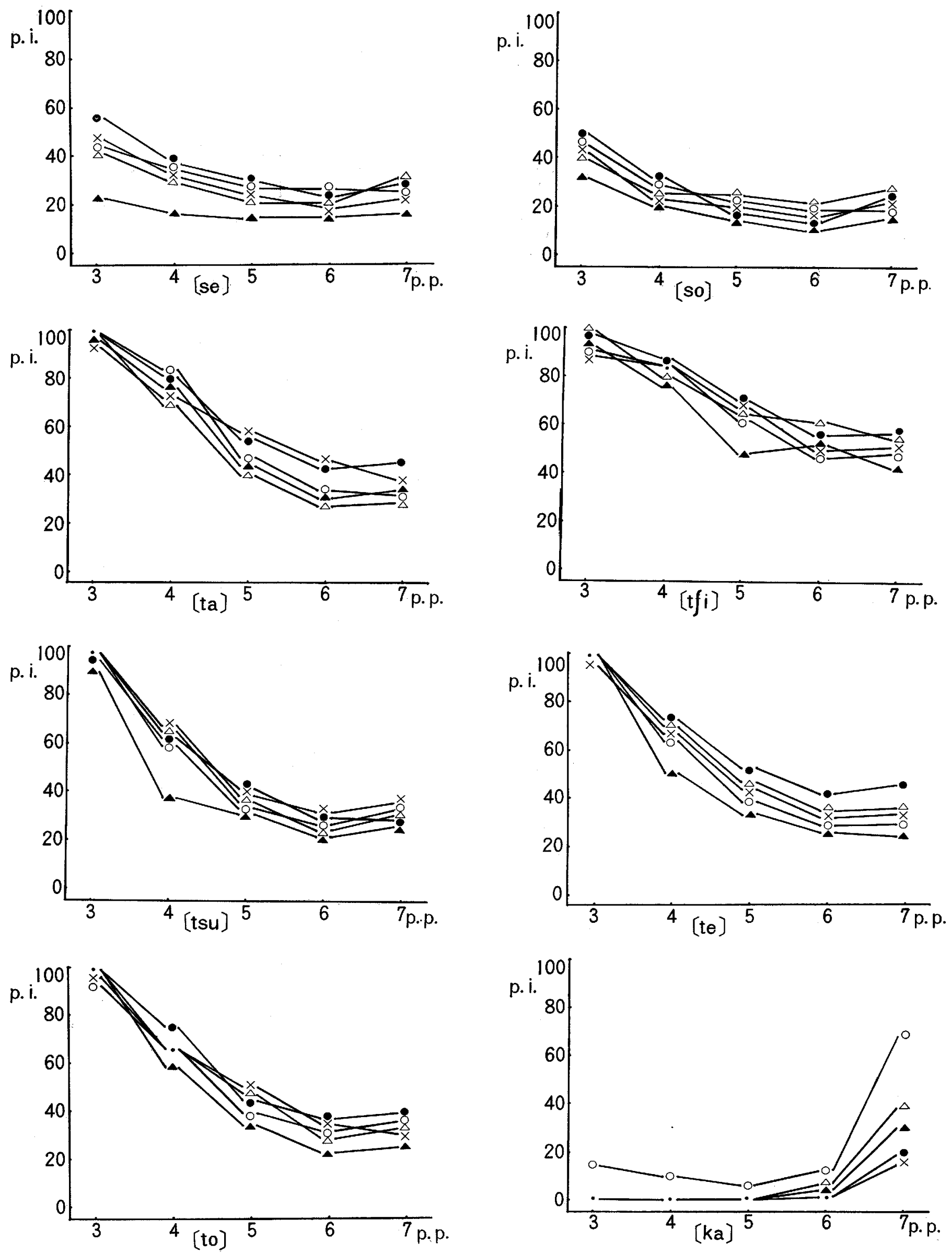

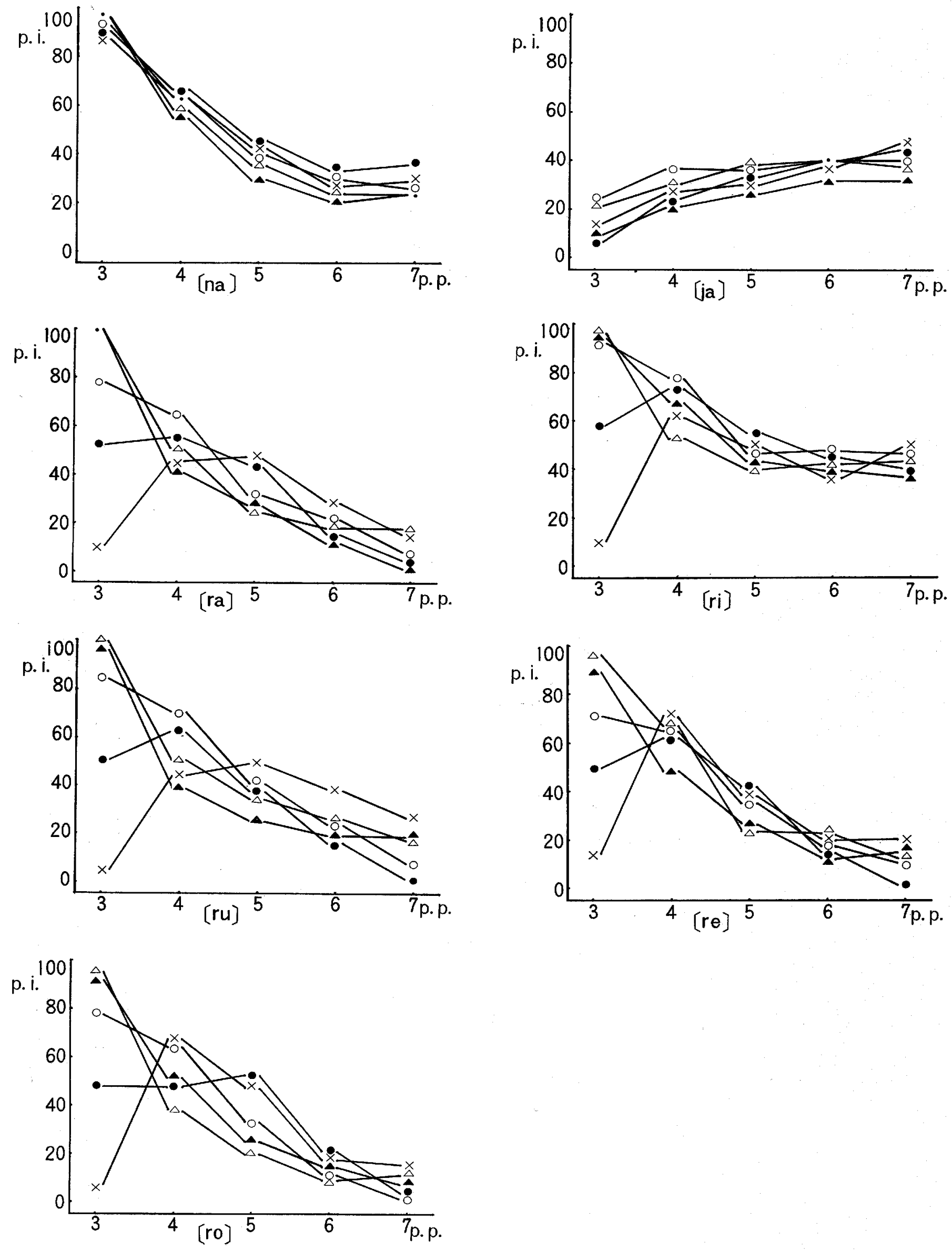
「カ」は，U型が多く，後方口蓋部での接触度合が高 く，「ナ」は，ほとんどC 型で, 前方口蓋部での接触度 合が高く,「ヤ」は，ほとんどV型で, 中間, 後方口蓋 部での接触度合が高かった。

滑音は，すべて H型で，中間口蓋部での接触度合が高 かった.

○舌小帯短縮症 2 ○群

術前は，滑音を除いた他の音のパラトグラムは，正常 者群のそれと同じ様相を示した，滑音は，ほとえどC 型 で, 前方口䔔部での接触度合が高く, 正常者群のパラト グラムと差異が認められた，術後は，滑音以外の音のそ れは，術前とほとんど変りはなかったが，滑音は，H型 の症例が増し, 中間口蓋部での接触度合が高く, 術前よ り変化して, 正常者群のそれに近い様相を示した。

。舌小帯短縮症 $3^{\circ}$ 群

滑音を除いた他の音のパラトグラムは，正常者群のそ れと同じ様相を示した．滑音はすべてC型となり，前方 口蓋部での接触度合が高く，正常者群のそれと著明な差 異が認められ，また，舌小帯短縮症 $2^{\circ}$ 群上屯異なって いた，術後は，滑音以外の音のそれは，術前之変りなか った．滑音も術前とほぼ同じく，術後の変化は，あまり 認められなかった。

\section{IV 舌小帯短緶症音声のサウンド・スペクトログラフに} よる音声分析的研究

\section{A. 研究目的および方法}

I. 目 的

電気音響分析器機であるサウンド・スペクトログラフ は，音声その他の一般的に複雑な音を周波数之時間の函 数として分析する装置である。この装置を用いて，舌小 帯短縮症音声を音響学的に明確にするととを目的とし た.

\section{2. 研究対象}

舌小帯短縮症 $2^{\circ} 2$ 名， $3^{\circ} 2$ 名計 4 名について，その 術前, 術後に録音し, 対象とした。

\section{3. 研究装置}

録音装置 : 舌小帯短縮症の語了度，語明度に関する研 究に使用したものに同じである。

分析装置：サウンド・スペクトログラフ（RION製）

(乙の分析装置は, 長崎大学医学部耳鼻咽喉科学教室 のあのを借用した。）

この装置は，音の周波数分析器として，現在最も精巧 な器機といわれている，その装置は。

1) Dynamic microphone

2 ）記録部
3）增幅执よび分析部

4) 電源部

5) Amplitude display unit

以上の 5 つに分けられる.

サウンド・スペクトログラフによって得られた記録図 形を，サウンド・スペクトログラムといい，縦軸に周波 数，横軸に時間，図形の濃淡によって音の強弱を示して いる. サウンド・スペクトログラムは，約 $10 \mathrm{~cm}$ 長の縱軸 に $85 \mathrm{c} / \mathrm{s}$ より $8000 \mathrm{c} / \mathrm{s}$ に至る周波数を, 約 $29.5 \mathrm{~cm}$ の横軸 に2.2秒間だけ音の分析をしうる．乙れには，45c/s と 300

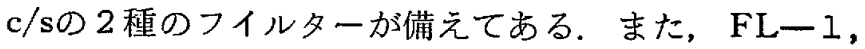
$\mathrm{Hs}, \mathrm{FL}-2$ の切替スイッチにより，録音，再生時の特 性を変化できる. Amplitude display unit は, 平均振幅 の時間的変化を記録するあのである。

4. 研究方法

被検音は，防音室内で録音し，乙の音声を通法のごと く，サウンド・スペクトログラフの磁気円盤にふたたび 録音し，それを繰返し再生しながら可变濾波器を通じて 分析する，な捄録音，再生とも増幅器の特性は， FL一 Iで，濾波は広帯域 $300 \mathrm{c} / \mathrm{s}$ で行なった。分析した語音 は，任意に選んだタ行音と，語明度，パラトグラムの観 察で，正常者群之差異がみられた滑音である。

\section{$\mathrm{B}$ ，サウンド・スペクトロクラム成績}

サウンド・スペクトログラフから得られた結果より, 舌小帯短縮症の術前, 術後に次のような差異 がみられ た. (Fig 5, Fig 6)

。舌小帯短縮症 2 群滑音

ラ：術前の先行子音部は，不明瞭で，起始はゆるやか であるが, 術後の先行子音部起始は，術前より著明に認 められた。母音のフォルマントに変化はなかった。

リ：術前の先行子音部は，明瞭で，短時間後に過渡的 な部分を経て母音に移行していた.術後の先行子音部は， 急激に始まり高い周波数成分もみられた。とのスパイク ・フィルが, 特徵であった.

ル：術前の先行子音部は，不明瞭で，低い周波数から 次第に上昇して母音に移行していた，術後は，先行子音 部の周波数成分が著明に指摘できた。

レ：術前の先行子音部は，不明瞭で，起始はゆるやか であった。術後は，「ル」と同じく，先行子音部が認め られた。

口：術前の先行子音部は，不明瞭で，短時間で母音に 移行していた。術後は，急激な起始で先行子音部がはじ まっていた，乙の点が術前と明らかに異なるところであ る. 
Fig 5

$$
\text { SOUND SPECTROGRAM (R-Sounds) }
$$

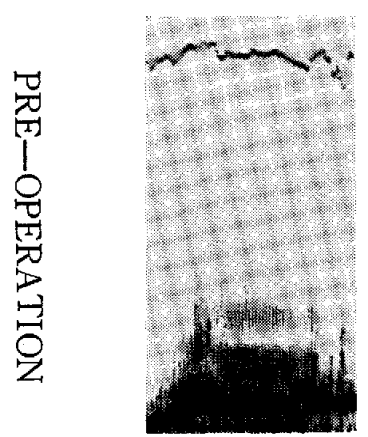

[ra]

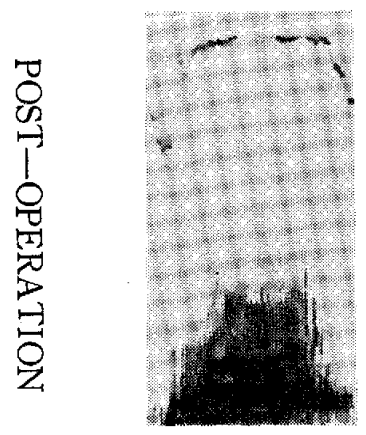

Fig 6

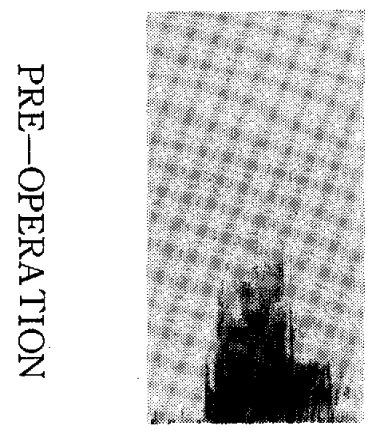

[ta]

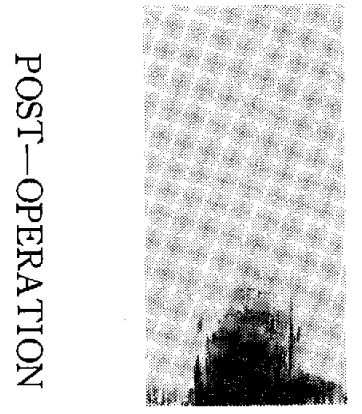

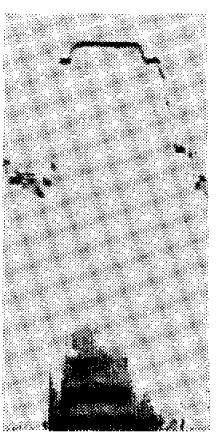

[ri]

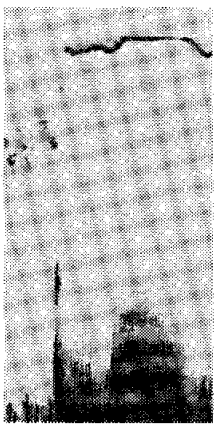

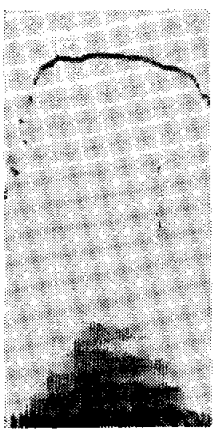

[ru]

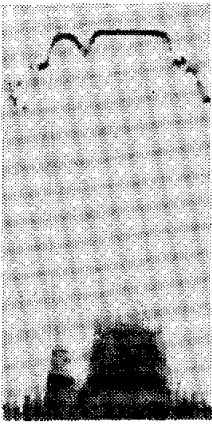

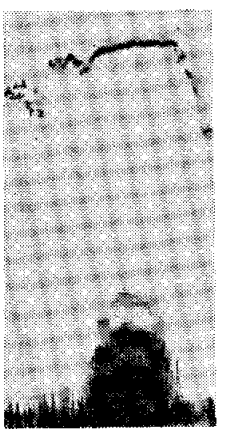

[re]

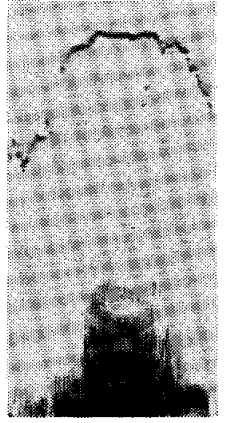

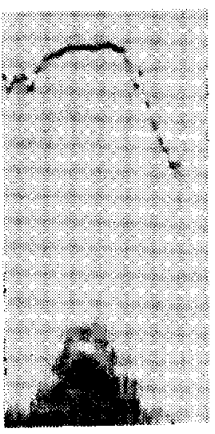

[ro]

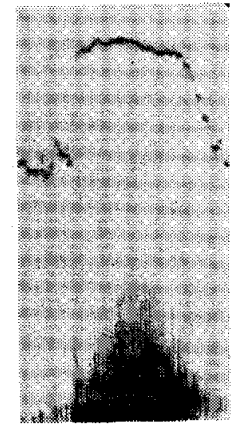

SOUND SPECTROGRAM ( $\mathrm{T}$-Sounds)
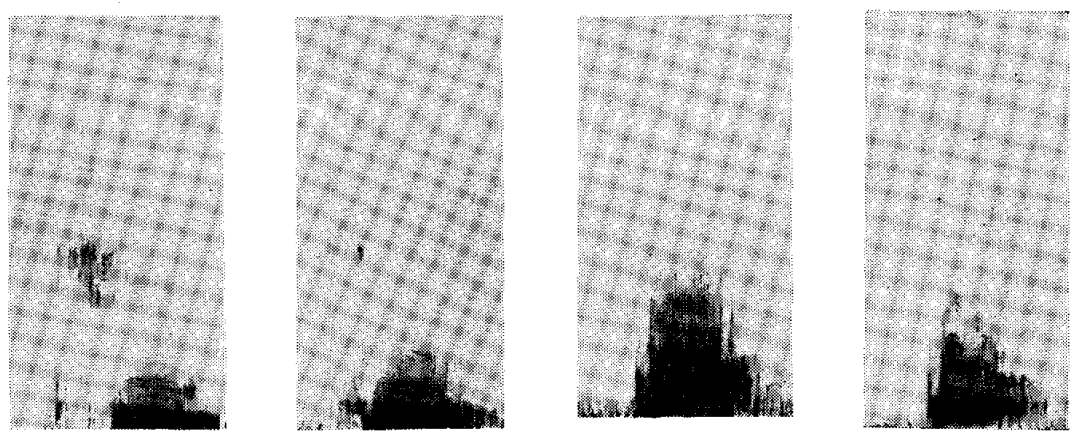

[to]

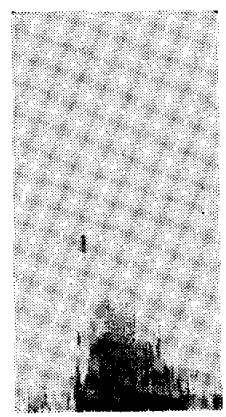


○舌小帯短縮症 2 群夕行音

タ：術前の子音部起始は，急激であるが，高い周波数 成分はみられなかれた. しかし，術後は， $6 \mathrm{~K} \mathrm{c} / \mathrm{s}$ 前後 の高い周波数成分がみられた。

チ：術前は，無声子音波が著明であり，術後に著しい 変化はなかった。

ツ：術前の子音部に無声子音波が認められた。術後 は, この無声子音波が著明で, $8 \mathrm{~K} \mathrm{c} / \mathrm{s}$ 前後の高い周波 数成分が認められる点が術前と異なっていた。

テ：術前の子音部起始は，急激であり，母音への移行 はゆるやかであった，術後は，術前に較へ，著明な違 いはなかった。

ト：術前は，「テ」と同じ所見がみられた。術後は， 術前と同じ所見であった。

。舌小帯短縮症 $3^{\circ}$ 群

滑音 : 術前の各音は，いずれも先行子音部が明瞭に認 められなかった，術後の各音は，いずれる先行子音部が 明瞭に認められた。これらの所見は，本症 2 群之同じ であった。

夕行音：術前の各音は，いずれあ無声子音波が明瞭に 認められた。術後は，語音により，乙の無声子音波に術 前にみられなかった高い周波数成分がみられた。 とれら の所見も，本症 2 群と同じであった。

\section{C. 小括}

舌小帯短縮症 4 名 $\left(2^{\circ}, 3^{\circ}\right.$ 各 2 名) について, 普通 に発音した滑音および夕行音を，術前と術後に，サウン ド・スペクトログラフで比較, 観察した.

。舌小帯短縮症 2 滑音

各音と屯術前は，先行子音部起始がゆるやかである. 術後は, 先行子音部起始が著明で, 特に「リ」の先行子 音部には，スパイク・フィルが認められた。 この様に， 術後, 先行子音部の周波数成分が著明にみられるように なった。

\section{。舌小帯短縮症 $2^{\circ}$ 夕行音}

各音と屯術前は, 急激な子音部起始で始まり, 無声子 音波が認められた。しかし，術後は，乙の子音部の無声 子音波に，さらに高い周波数成分がみられるようになっ た語音もみられ，乙の点が術前と異なっていた。

。舌小帯短縮症 $3^{\circ}$ 群

術前, 術後の滑音, 夕行音の所見は，舌小带短縮症 $2^{\circ}$ 群のそれと，ほぼ同じ様相を示した。 つまり，周波 数成分の分析で, 本症 $2^{\circ}$ と $3^{\circ}$ の雨群を比較して差異は 認められなかった。

\section{$\mathrm{V}$ 総括ならび考察}

\section{A. 研究方法について}

舌小帯短縮症は，いろいろの名称で呼ばれているが, 舌小帯の短縮により，舌尖を充分に挙上あるいは口の外 に出すことが出来ず，このために舌尖の運動範囲が制限 される疾患である( 8)，音声学において，舌は音声器官 として非常に重要な役割をなしている40〜43)．このた め, 舌の形態異常の一つである舌小帯短縮症には，言語 障害が指摘され，とくに滑音障害を来たすといわれてい る1〜8). しかし，本症の言語障害について，主観的な聴 覚による観察報告はみられるが，その詳細な科学的研究 については定かでない，そとで,私は聴覚的研究パラト グラムによる調音研究, 電気音響学的な音声分析的研究 により, 舌小帯短縮症の音声言語学的研究を行なった。

聴賞的研究方法としては, 語了度検査, 語明度検查の 2 方法がある，本症の術前，術後に両検查を行うことに より，本症の言語障害の程度を判明することができると 考え，両検査をあわせ行なった，語了度検査とは，有 意味音節の検查法である。この方法には，Lee Edward Travis44)などの intelligibility という考えや，江口45) の方法などがあるが, 田緣22)が行なっている語了度検査 法によった，検查語集は，田縁22)が作製した検査語集を 用いた，語明度検査は，岡本23)，降矢24)，宮崎46)，高寄 25)が言語障害の成績を検討するのに都合が良い方法であ るとした, 無意味音節語明度検査に準じた。検查語集は。 高寄25)の変法で，単音節，無意味 3 音節の検査語集を均 一性を配慮して作製した。

語明度検查に势ける検者について，降矢 ${ }^{24)}$ は，一般人 5 名で検查し, 中間の值 3 名の平均值を語明度とし, 平 野47)は，20名の平均值を語明度とし，清水達48)は，10名 の平均值であらわしている，高寄25) は，検者が一般の人 では，ことばの明瞙性に一定の規則性がなく，検查結果 に個人差を生ずるが，言語治療を行なっている者では， より客観的な判断が自から規制され，正しい弁別がで き，検者相互の成績に有意な差がないといっている，私 達の研究22)でも，言語治療を行なっている者が検者であ れば，個人差はなかった，そこで，私は，これらの検討 にもとずき，3年以上の言語治療に経験ある私が，語了 度，語明度検查の検者となり，特に語明度検查は，2 組 の検査語集を用い，その平均值を語明度とした。

聴取環境について，池尻等49)は，雑音が語明度に大な る影響を与えると述べ，直接聴取と録音して後の聴取に ついては，降知）が両方法に有意義な差がないととを立 証している，そこで，私は，語了度，語明度検査とも， 
雑音のない聴力検査用防音室で発 音させてててれを録 音し、後で再生装置を用いて聴取分析検査した。

音声の調音について分析することは，音声言語学の主 要な研究である ${ }^{30,41)}$. この調音運動時の舌の動きを記録 する方法として，パラトグラフィ，リンゴグラフィが用 いられている.

パラトグラフィは，1871年英人霜科医 J. Oakley Coles 50) によって始められたとされ，その後多くの研究 報告がなされている. パラトグラフィの記録の方法に，

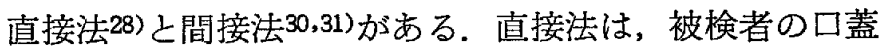
に塗料，顔料を塗布し，発音に際し，舌の接触により粉 末が拭い去られた口蓋の図を観察する法である，との方 法は，いろいろの利点もあるが．記録を保存出来ない欠 点がある．この欠点を補うために，間接法が考えられ た。しかし，間接法の場合，口蓋板の違和感が問題とな り，悬田299は，口蓋板の厚さが日本語に与える影響を検 討している，森田31は，口蓋板材料の条件として，」） 厚さがうすく均一，2）違和感が少い，3）変形しない, 4) 保存可能，5）製作が簡単，などを挙げ，てれらの 条件をみたす材料として，硬質ビニール板がよいとして いる，私は，口腔外科に扔ける保護床の製作法に準じて， 合成樹脂板で口蓋板の製作を行なった。製作方法は，森 田31)の方法之同じであった。

口蓋板に塗布する物質についても，従来，墨汁を始め いろいろの屯のが試みられている。森田31は，ワゼリン

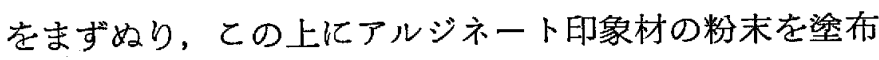
してパラトグラムの採取を行なっている．私は，口蓋板 の水洗が簡単なように，口蓋板に水溶性糊材を妨，そ の上にアルジネート印象材粉末を塗布して使用した。

パラトグラムの観察方法は，J. Oakley Coles50) を始 めとして，多くはただ主観的に観察あるいは比較した あのが多い. 荒井30)，森田31)は，正常者に括ける日本 語音声のパラトグラム分析方法について述べている. 荒 井30)は，日本語 100 音を， V, C, N , H, Uの 5 型に 分け，パラトグラムが調音点抢よび調音領域をきわめて 忠実に反映して，調音上の特徽を示していると述べてい る.森田31)は，パラトグラムを数量的にあらわすため に，座標分析法と口蓋区分法を考案し，両方法の観察よ り，パラトグラムには個体内変動がないととを確認して いる．私は，口蓋の大斗さに対するパラトグラムの接触 部分を，口蓋幅径を 100 とする示数であらわした。この 方法は, 各人各音の口蓋部位別の接触度合を知る方法之 して，便利な分析方法であると考える．乙の方法をパラ トグラム示数計測法とした.
正常者以外におけるパラトグラムについて, 荒井51 は, 䨑牙欠損者, 粜列不正者, 口蓋裂者を，また，山 本52)は，不正咬合者の日本語音声を観察している．しか し, 舌の形態, 機能異常がパラトグラムに与える影響に ついては，末だ研究されていない，そして，舌形態異常 の一つである舌小帯短縮症の調音をパラトグラムで観察 した報告もない.

音声などの一般の音は，非常に複雑な波形をしている が，乙の複雑な波形を分析し，如何なる周波数に如何な る成分があるかを時間的に示すのが周波数分析であり， サウンド・スペクトログラフは, 音声等を周波数分析す る一種の周波数分析器である.

この装置は, 1946年W. Koenig, H. K. Dunn, L. Y. Lacy がR. K. Potter によって初ぬて提案された方 法を改良して，「サウンド・スペクトログラフ」とし て，J，A． S，A誌上に掲載した報告に基ずいて，商 品化されたものである33)。本邦には，関33)が1953年に紹 介して以来, 関33), 弘田53), 釜本54,55)は, 正常日本語音 声の分析を, 釜本56), 平野47)は, 口蓋裂音声の分析, 弘 田57)は, 口空内異物の影響について, 山本58)は, 不正咬 合者の音声について分析している. 舌小帯短縮症音声の 本装置による分析は，みられないが，宮野59)は，実験的 な舌小帯短縮音声に扔ける滑音を, サウンド・スペクト ログラフにより分析観察を行なっている.

\section{B. 研究成綡について}

舌小帯短縮症の語了度検査の結果, 3 音節語了度は, 正常者が99\%以上であるのに対し22)，本症は，82\%以上 であった，てのととは，田縁22)が述べているでとく，日 常会話では，前後の語句の関係により，意志の伝達は だいたい出来るし，実社会において，さほどの不自由を 感じることはないが, 聴取者は, 異常な感じをむつこと を意味している. 舌小帯形成術以外に調音器官の変化が ない本症術後は, 術前に較べ, 3 音節, 2 音節語了度亡 あ, 語了度の上昇した症例が大多数であった。このとと は, 術前の語了度の低下の原因として，本症が影響して いることをうらずけている。

語明度検査の結果, 本症術前の単音節語明度は, 70.1 96 以上あった。降矢24) は, 単音節語明度70〜96\%で, 被 検者の言葉について，特に注意をはらわなくとも大略理 解出来るのを軽度言語障害としている. 本症の結果は, この軽度言語障害に該当する，術前の無意味 3 音節語明 度検查の結果, 宮崎46)が, 口蓋裂音声について述べてい る様な特性はみられなかった。本症術後の語明度検査の 結果, 単音節, 無意味 3 音節と屯に, 術後は, その語明 
度の最高，最低值は上昇していた。 また，単音節，無意 味 3 音節とも，術前に較へ，術後にその語明度の上昇を 示した症例が大多数であった。これらの結果は，手術以 外に調音器官の変化はないととより, 手術によっを, 言 語障害が改善されたことを意味している。

語音別語明度検查の結果, 術前に較べ，術後に語明度 の上昇が最も著明にみられたのは，滑音で，その次に八 行音, 鼻音の順であった。

パラトグラムの観察結果, 正常者群のパラトグラム は，荒井30)，森田31)のそれと同じ様相を示した，本症 $2^{\circ}$ 群, 本症 $3^{\circ}$ 群の術前, 術後亡屯, 母音, サ行音, 夕 行音, 力,ナ，ヤ音は，正常者群のパラトグラムと同じ 様相を示した. しかし，本症の滑音のパラトグラムは， 正常者群のそれ之異なっていた。すすなわち，本症 2 。群 の術前は，正常者群之異なった様相の症例が多く，調音 の異常が認められた，しかし，術後は，正常者群と同じ 様相を示す症例が増していた，このように，本症の中等 症は，調音の練習をしなくとも，舌小帯形成術だけで， 正常者に近い調音をするようになることが認められた。 これに対し，本症 $3^{\circ}$ 群の術前は，正常者群のそれ之著 明な差異を示し，調音の異常をなしていた。術後は，術 前に較べ，大きな変化はなく，やはり，正常者と明らか に異なっていた，このてとは，本症の重症では，調音の 異常が悪習慣として残り，調音の練習をしないで，舌小 帯形成術を行なっただけでは，舌の口蓋への接触異常は 改善されないことが認められた。

サウンド・スペクトログラムの観察結果, 本症 $2^{\circ}$ 群 における術前の滑音所見は，宮野59)の実験的舌尖固定時 之類似して，先行子音部が不明暸であった。，術後は，先 行子音部が明膫にみられ，音によっては，著明なスパイ ク・フィルが認められた。 術前のタ行音は, 先行子音部 亿無声子音波がみられたが，術後，無声子音波に高い周 波数成分がみられるようになった語音むあった。これら の所見は，本症 $3^{\circ}$ 群でも $2^{\circ}$ 群之同様の様相を示し，両 者間偖異はあまりなかった。

以上のととがらを語音別にみると，母音，半母音は， 各観察研究結果とも, 正常者群, 本症術前群, 本症術後 群の3群間に差はなかった。乙れは，高橋60)が述べてい るごとく，母音は，口の構えと舌の形が明瞭度を左右 し，舌尖は，普通積極的役割を演じていないため40)と考 えられる、けれども，鼻音，八行音は，舌で口腔を閉す ことが第1義であり，舌そのものの調音運動は第 2 義で あるのに40術前語明度の低下がみられた。 また, 有声， 無声子音では，舌尖は主体的に働いていないのに，タ行
音の先行子音部の周波数成分が，術後わずかではあるが 変化していた．乙れらの語音発音時，舌尖は，すみやか かつ精細に動き，1/200 秒で子音を発するといわれてい る40)。しかし，本症の術前は，舌尖の可動範团が狭いた め,パラトグラムにあらわれない舌尖の動きを悪くし， 術後は，舌尖の可動範囲も広まり，舌尖の動きもよくな ると考えられる, このために, 鼻音, 八行音, 有声, 無 声子音の語明度やサウンド・スペクトログラムの所見に 術後変化がみられたと考えられる，滑音では，各観察研 究結果とも, 正常者群, 本症術前群, 本症術後群の 3 群 間に著明な差異がみられた。すなわち，本症の術前は， 舌の挙上が充分に出来ないために，パラトグラムでみ られたごとく，調音の異常を示し，サウンド・スベクト ログラムでみられたように, 先行子音部の周波数成分が 不明瞭となり，滑音の語明度の低下を示していた。これ は，理論的に最大の舌尖挙上を要する滑音が障害される はずであるという，田口21)の仮説と一致した，しかし， 術後は，正常者之同じパラトグラムの様相を示す症例が 増し，先行子音部の周波数成分が明暸となり，滑音語明 度の上昇がみられた。 この様に, 本症は, 滑音に特に大 なる影響を与えているととが確認された。

以上のごとく. 舌小帯短縮症の音声は, 語了度検査で 示されるごとく, 日常会話では, 前後の語句の関係に より, 意志の伝達を大略了解出来るが, 語明度検査の結 果，降矢の軽度言語障害に該当する，これは，滑音で明 らかなように, 本症の舌尖挙上の不全が原因で, 調音の 異常をきたし，乙のために，先行子音部の周波数成分は 不明瞭となり，語明度は低下することが明らかとなっ

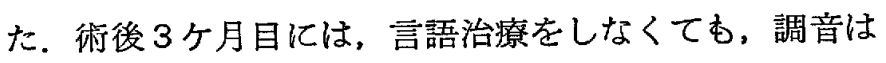
正常者に近い様相となり, 先行子音部が明瞭となり, 語 明度, 語了度の上昇となって, 術後に言語障害の改善が 確認された。すなわち，言語治療をしなくても，舌小帯 形成術を行なうことにより，本症の発音への影響は，少 くなることが判明した. 以上の結果より, 音声言語学的 に，本症はすみやかに舌小帯形成術をなされるべきであ るといえる.

\section{VI 結}

私は, 自分で考案した舌伸展度 測定器を使 用して, 8767 名を調查し, 舌小帯短縮症 $2^{\circ}$ (中等症) 75名, $3^{\circ}$ (重症) 8名中より, 協力の得られた症例者, $2^{\circ} 8$ 名, $3^{\circ} 5$ 名に舌小帯形成術を行なった。乙の術前, 術後 K，1）語了度, 語 明度検査，2）パラトグラムの観 察，3）サウンド・スペクトログラムの観察を行ない, 正常者, 本症術前, 本症術後の3群について, 此較検討 
して, 舌小帯短縮症の音声言語学的研究を行ない，つぎ の結果を得た。

J）語了度検查に打いて，本症術前の3 音節語了度 は，82\%以上であった，てれは，日常会話には，さほど の不自由はないが，聴取者がやや異常な感じをもつこと を意味する，また， 3 音節， 2 音節とも，術前に較へ， 術後の語了度の上昇が大多数の症例にみられ，術後に語 了度の改善が認められた。

2) 語明度検查において，本症術 前の 単 音 節語明度 は，70.1\%以上であった。乙れは，降矢の分類した軽度 言語障害侅当する，また，単 音節，無意味 3 音節之 屯, 術前に較べ, 術後の語明度の上昇が大多数の症例に みられ，術後に語明度の改善が認められた。

3) パラトグラムの観察によると，本症の滑音以外の 語音は，正常者のそれと比較して異なった様相はみられ なかった，しかし，本症術前の滑音は，正常者のそれと 異なる様相を示した，術後に，本症 2 群の滑音は，正 常者のそれと近似した様相を示したが，本症 $3^{\circ}$ 群は， 術前のそれとあまり変りはなかった。

4）サウンド・スペクトログラムの観察によると, 本 症は，滑音の先行子音部が術前に不明瞭であったが，術 後は著明にみられた，夕行音の無声子音波は，術前にく らべて，術後その周波数成分の変化がみられた．

5 ）語音別にみると，滑音以外の語音は，各観察結果 とも，いちちるるい異常はみられなかった，しかし，本 症の滑音は，語明度，パラトグラム，サウンド・スペク トログラムで異常がみられ，本症の影響が特に滑音に大 なるととが確認された，滑音の術後は，各観察結果之 あ,その改善がみられた。

以上のごとく，本症の音声は，言語障害をなしてい た。しかし，本症の言語障害は，舌小帯形成術を行なう ことにより，言語治療をしなくても改善されることが判 明した。このととより，音声言語学的にみた場合，舌小 帯短縮症は，すみやかに舌小帯形成術を行なうべきであ るといい得る.

（稿を終るにあたり，御指導，御校閲を賜った池尻茂 教授に梁甚なる謝意を表します。また種々御教示にあず 汃た古本克磨助教授，熊本大学田縁昭講師に感謝の意 をあらわすととむに，御協力くださった教室の諸先生に 御礼申し上げます。また防音室および器機老借用させて いただいた熊本大学耳鼻咽喉科学教室, 長崎大学耳鼻咽 喉科学教室にお礼申し亡げます。)

この論文を本研究中に他界した父提健一郎に棒ぐ.

\section{VII 引文 嗝}

1. 嗃藤至六郎; 口腔外科通論及び手術学，513，歯科 学報社 (東京), (1937).

2. 佐藤運雄; 口腔外科学, 66-67, 金原商店 (東 京), (1938).

3. 大井 清; 口腔外科学 (各論), 16, 永末書店 (京 都), (1958).

4. Thoma, K. H ; Oral Surgery, 1564-1566. C. V. Mosby Co. (Saint Louis), (1963).

5. Archer, W. H. ; Oral Surgery, 250-253, W. B. Sannders Co. (Philadelphia), (1966).

6. 後藤敏郎; 耳鼻咽喉科学 (下巻).974, 医学書院 (東京), (1960)

7. 切替一郎; 新耳鼻咽喉科学, $328-329$, 南山堂 (東京), (1967)。

8. 鳥居恵二; 耳鼻咽喉科学, 435, 南山堂 (東京), (1966).

9. 西 正勝; 舌癒着症の統計的ならびに臨床的研究： 医学研究, 39, 35-57, (1969).

10. 藤林 平他; 舌繫帯癒着症の工例 : 口病誌, 12 , 249-250, (1938).

11. 渡辺義男 ; 先天性舌小帯過短症 : 歯科学雑誌, 4, 272-278, (1947).

1.2. 飯岛勇三; 舌小帯短縮症 : 信州医誌, 13, 217一 218, (1964).

13. Samuel G. Fletcher, et al ; Lingual function and relative length of the lingual frenulum : Jounal of speech and hearing research, 11, 382 -390 , (1968).

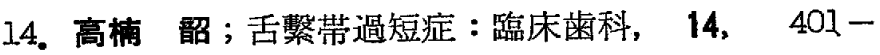
404, (1942).

15. 本問弥三郎; 舌繫帯翼常に依る「力」行発音障害 : 日耳鼻，51，207，(1948）。

16. 杉田 博; 舌癒着症 : 児科診療, 16, 38-40, (1953).

17. 山崎秀治他; 舌小帯癒着症12例：日本歯科医師会歯 科医学会誌，5，96，(1954)。

18, 安野友博他; 舌小帯短縮症例の言語 : 耳鼻臨床, 57, 362, 448, (1964).

19. 上野 正; 歯科に打ける言語治療の展望 : 日本歯科 医師会雑誌，21，3-9，(1968).

20. Eugene T. Mc Enery, M. D., et al : Tonguetie in infants and children : J. Pediat, 18, 252 -255 , (1941). 
21. 田口恒夫；歯牙の異常・舌の異常亡言語障害：歯界 展望，16，110-l17，(1959）.

22. 田緣昭他; 口蓋裂患者の発語明瞭度と了解度との関 係について：九州荬会誌, 21，249-251，(1967).

23. 岡本途也他; 語音発語明瞭度検査法について：耳 喉, 28, 587-591, (1956).

24. 降矢宣成; 言語障害の語音発語明瞭度 (語明度) に 関する研究：日耳鼻，61，1922-1948，(1958).

25 .高寄 昭 ; 口蓋裂異常音声の語音発語明膫度検査 ならびに口蓋裂の手術時期に関する研究 第卫編 語音発語明瞭度検查の検討：阪大歯学誌，9，7989, (1964).

26. 梅野正義; 高圧レ線映画による語音発声時の軟口蓋 ならびに舌根部運動に関する研究：耳鼻踟休，55, 305-336, (1962).

27. 和田皋郎; $\mathrm{X}$ 線映画法による構音運動の解析：阪大 宷学誌, 13, 105-122, (1968).

28. 懸田克躬; 日本語ノ構音二関スル考察, 第一 日本 語音ノ口蓋図並ビニ舌図二就テ：口病誌，11，136 -145, (1937).

29. 緊田克躬; 日本語ノ構音二関スル研究, 第二 語音 ノ発音二及ボス人工口盖及ビ前歯舌面ノ厚サノ影響

: 口病誌, 11, 195-205, (1937).

30. 荒井堅一; パラトグラムによる日本語調音の生理学 的研究 第工篇 正常篇：歯科学報，58，(10），1 -16, (1958).

31. 森田啓一; 正常者のパラトグラム：口病誌，34, 279-309, (1967).

32. 笛谷享三; 口盖破裂患者の手術前後に打ける発声音 色の変化に関する研究 : 歯科学報, 52, 217-222, 258-264, (1952).

33. 関 英男; Visible speech亡日本語発音のSonagram : 電気学会雑誌, 73,922-927, (1953).

34. 小橋 豊; ソナグラフ：日本音響学会誌, 11, 57 -64, (1955). 35.

35. 金本安敏他; Sona-graph について：耳鼻臨床, 49 , 785-790, (1956).

36. 堤 直文; 熊本目下に拈りる舌小帯短縮症の発現率 一舌伸展度測定器についてー：九州歯会誌, 23, $297-303$, (1969).

37. 明瞕度委員会; 明睹度試験法の規準, 日本音響学会 編, (1957).

38. 滕田敏彦他; 生理学講義 下巻, 330-348, 南山堂 (東京), (1964).
39. 市岡正道他; 歯学生理学, 457-472, 医歯薬出版, (東京), (1.967).

40. 服部四郎; 音声学, 岩波書店 (東京), (1967).

41. Wendell Jishnson, et al ; Diagnostic Methods in Speech Pathology, Harper \& Row Publishers (New York), (1963).

42. 大和田健次郎他; 恥えとことばの障害, 医学書院 (東京), (1966),

43. 林 義雄；こえとととばの科学，鳰鳴堂書店（東 京), (1968).

44. Lee Edward Travis et al; Handbook of Speech Pathology, Appleton-century-crofts INC (New York), (1957).

45. 江口実美他; 口蓋欠損が音声言語に及ぼす影響につ いて：耳喉，39，867-875，(1967).

46. 宮崎 正; 口蓋裂患者の異常音声に関する研究：阪 大歯学誌, 4, 21-58, (1959).

47. 平野 実; 口蓋裂音声の音声学的研究 : 耳鼻臨床, 56, 124-163, (1963).

48. 清水達夫他; 形成外科的手術を施した下顎前乫症患 者に就いての音声学的観察 : 京大口科紀要, 5, 86 -96, (1965).

49. 池尻 茂他; 口蓋裂患者の発語明暸度と各種の条件 について1。雑音の影響：口科誌, 16, 159, (1697).

50. Oakley Coles, $\mathbf{J}$, ; Transaction of the odontological society of Great Britain, (1871) (县䉥田 ${ }^{28)}$ による)

5L. 荒井堅一；パラトグラムによる日本語調音の生理学 的研究 第 2 篇 異常篇: 菡科学報, 58, (10), 16 , (1958).

52. 山本 陽; 不正鮫合者のサ行変化について一特にパ ラトグラムの計测について一：日矯歯誌、23, 9395, (1964).

53. 弘田仁哉; ソナグラムによる発音の研究 : 雪科学 報，56，180-189，(1956).

54. 釜本安敏; 日本語母音特性の Sonagraph Kよる研 究: 耳鼻臨休，50，28一-35，(1957).

55. 金本安敏; 日本語音声の構音機構に関する電気音響 器機による分析的研究 第1編 正常日本語音声の電 気音響器機による分析的研究：耳鼻臨床，51, 536-552, (1958).

56. 金本安敏; 日本語音声の構音機構に関する電気音響 器機による分析的研究 第 2 編 異常 (構音障害) 日 
本語音声の電気音響器機による分析的研究 : 耳鼻臨 床, 51, 553-574, (1958).

57. 弘田仁哉；ソナグラムによる発音の研究 : 歯科 学 報，56，224-231，271-273，300-305，353358, (1956).

58. 山本 陽; 不正咬合者の音声学的研究 (その2) : 日矯歯誌，18，177-178，(1959)。
59. 宫野和夫; 舌小帯短縮によるラ行構音障害の実験的 研究; 耳喉, 33,499-501, (1961).

60. 高橋宏明他; 口の構えと舌の形が日本語母音明瞭度 に及ぼす影響：音䒠科学研究，2，71-82, (1962). 